\title{
A Study of the Staining Effect of Roselle (Hibiscus sabdariffa) on the Histologic Section of the Testis
}

\author{
Estudio de los Efectos de Tinción de la Rosa de Jamaica \\ (Hibiscus sabdariffa) en Cortes Histológicos de Testículo
}

Egbujo, E. C.; Adisa, O. J. \& Yahaya, A. B.

EGBUJO, E. C.; ADISA O. J. \& YAHAYA, A. B. A study of the staining effect of Roselle (Hibiscus sabdariffa) on the histologic section of the testis. Int. J. Morphol., 26(4):927-930, 2008.

SUMMARY: This study describes the preparation and use of Roselle (Hibiscus sabddariffa) for the differential staining of testicular tissue sections to find out its staining effect on nuclear, cytoplasmic and other structures. Various treatments using modifications of the plant extract in water were carried out on sections of the rabbit testis. Various levels of differentiation of nuclear and cytoplasmic structures as well as other structures of this organ was obtained especially when $1 \%$ eosin was applied as a counter stain. The best staining result was obtained when iron alum was used to mordant the extract and when the extract, mordanted with potassium alum was acidified using acetic acid and used to stain the sections. Modification of the aqueous extract to an alkaline $\mathrm{pH}$ using ammonia gave the poorest staining effect. Roselle extract therefore shows reasonable potential as a candidate nuclear stain especially when modanted with iron alum or mordanted with potassium alum and acidified with acetic acid.

KEY WORDS: Hibiscus sabdariffa; Staining; Testis; Histologic section.

\section{INTRODUCTION}

Staining techniques originated from the second half of the last century (Kolliker, 1852). Stains have been used to enhance accurate descriptions of the microscopic structure of tissues, which is necessary for histopathologic diagnosis. Plant and insect parts have found place in histological staining due to their colouring and dying effect. Examples of plant and insect parts that have found place in histological staining as natural dyes are Haematoxylon campechiaumn, from which haematoxylin is obtained (Bohmer, 1865) and Dactylopius cacti, from which carmine stain is obtained (Goppert \& Cohn, 1849). Although most of the dyes in current use in histopathology laboratories are of synthetic origin, natural dyes still hold promise as a potential source cheaper dyes and consequently providing employment opportunities in developing countries. Aqueous extract of Hibiscus sabdariffa has been recently used to stain lymph node and kidney biopsies. The trial was however without clearly defined treatments.

The staining was done at $56{ }^{\circ} \mathrm{C}$ for $1 \mathrm{~h}$. The results obtained were said to be similar to that of silver impregnation techniques and the conventional haematoxylin and eosin method.
This study aims at demonstrating the dyeing effect of Hibiscus sabdariffa on tissue sections and to find out the effect of mordants; $\mathrm{pH}$ and duration of staining and temperature on the staining property of Hibiscus sabdariffa.

\section{MATERIAL AND METHOD}

Preparation of Hibiscus sabdariffa extract and staining solution. The dried succulent red calyx of Roselle (Hibiscus sabddariffa) was purchased in the market and ground to powdery form using pestle and mortar, sieved and stored in a dry container. A measured quantity of the ground powder of Roselle was brought to boil in water, and mixed by shaking vigorously. This was allowed standing for 30 minutes, then filtered to obtain the coloured extract.

Fixation, Preparation of sections and staining of sections. The selected pieces of testicular biopsy obtained from a rabbit were fixed in $10 \%$ formalin. These were processed through ascending grades of ethanol and two changes of absolute 
ethanol, cleared in three changes of xylene and then infilterated with molten paraffin wax $\left(60^{\circ} \mathrm{C}\right)$. The testicular biopsies were then embedded in paraffin wax, sectioned at 5 $\mu \mathrm{m}$ and stained appropriately with various modifications of the extract as tabulated below. They were subsequently des hydrated, cleared and mounted with DPX. Photomicrographs of the sections were then taken.

\section{RESULTS AND DISCUSSION}

The haematoxylin and eosin staining of the testis (Fig. 1) showed a deep red stained outer fibrous layer, the tunica albugenae, beneath which are seen a number of seminiferous tubules cut in various plains. Between the tubules are connective tissues containing blood vessels and groups of interstitial cells. Each seminiferous tubule is lined by several layers of cells, which when viewed under high power magnification reveals an indistinct cell boundary and prominent nuclei. The outer rows of nuclei belong to sustentacular cells and spermatogonia. Passing inward towards the center of the tubules are large nuclei of spermatocytes and many smaller nuclei of spermatids. No matured spermatozoa were seen.

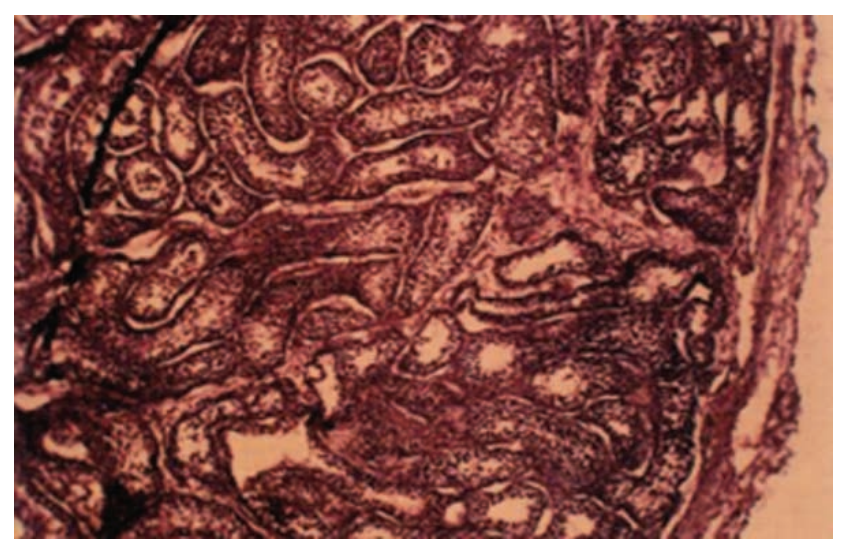

Fig.1. Histological section of the testes stained using the hematoxylin and eosin method as a control section. It shows clear nuclear/cytoplasmic differentiation with numerous seminiferous tubules and the outer tunica albuginea.

In the test slides stained with Roselle extract mordanted with potassium alum and counter stained with eosin (Fig. 2), the section of the testis showed a better nuclearlcytoplasmic differentiation compared to that given by the haematoxylin and eosin method. The slight improvement in nuclear staining as compared to when the extract was not mordanted could be attributed to the possible formation of a mordant and dye complex known as a 'dye-lake'. These are similar to the haematoxylin-mordant complex, which are usually positively charged, and therefore behave as cationic dye at low $\mathrm{pH}$. When used to stain tissues, cationic dye-mordant complexes are attracted to negatively charged sites, displaying a particular affinity for polyphosphates. This explains the affinity for the nuclei (Marshall \& Horobin, 1973). The poor nuclear/ cytoplasmic differentiation seen in the use of unmordified Roselle extract and eosin as compared to haematoxylin and eosin may highlight the need for an auxochrome which stabilizes a staining reaction as obtained in the haematoxylineosin method.

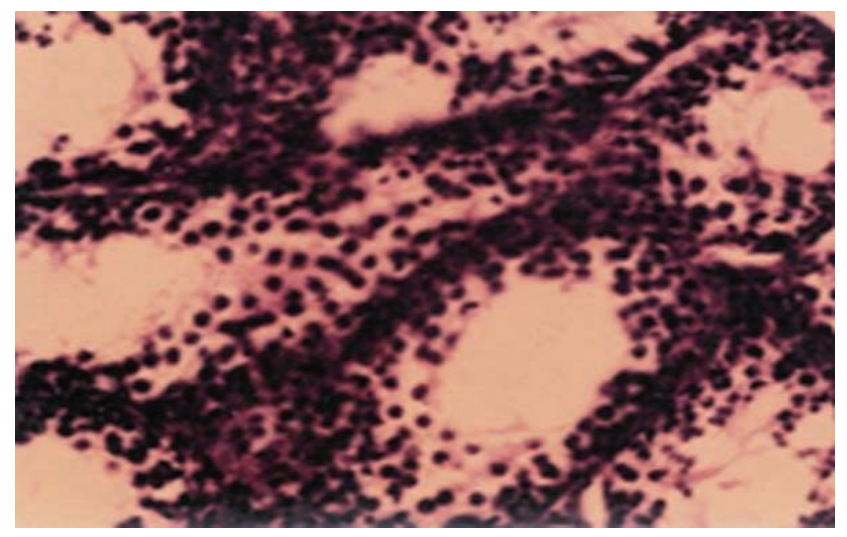

Fig. 2. Histological section of the testes stained using roselle extract which was mordanted with potassium alum and counterstained with $1 \%$ eosin. The nuclearlcytoplasmic differentiation is not as good as in haematoxylin and eosin method.

Roselle extract mordanted with potassium alum, acidified with acetic acid and counterstained with eosin, (Fig. 3) showed that in the testis, the nuclear staining is particularly enhanced. The nuclear/cytoplasmic differentiation is markedly enhanced although affinity for eosin seemed to be reduced. This shows that the Roselle dye molecules are charged and that the ionic charges could be varied using acids or alkalis and therefore, its application as a nuclear or cytoplasmic stain made possible. The reduced cytoplsmic staining when acetic acid was incorporated in the roselle extract also suggest that the presence of nucleic acids in the cytoplasm, though not in the same quantity as in the nuclei, attracts and therefore reacts with the dye resulting in the blockage of reactive sites that would have been taken up by the counterstain.

This has been documented by Birkedal-Hasen (1973), where he reported a similar phenomenon in the heamatoxylin and eosin method. The implication of this is that, where cytoplasmic structures or other structures are of interest, an appropriate $\mathrm{pH}$ that would favour the uptake of the stain would have to be selected.

When roselle extract mordanted with potassium alum, alkalinized with ammonia was applied on the testicular 


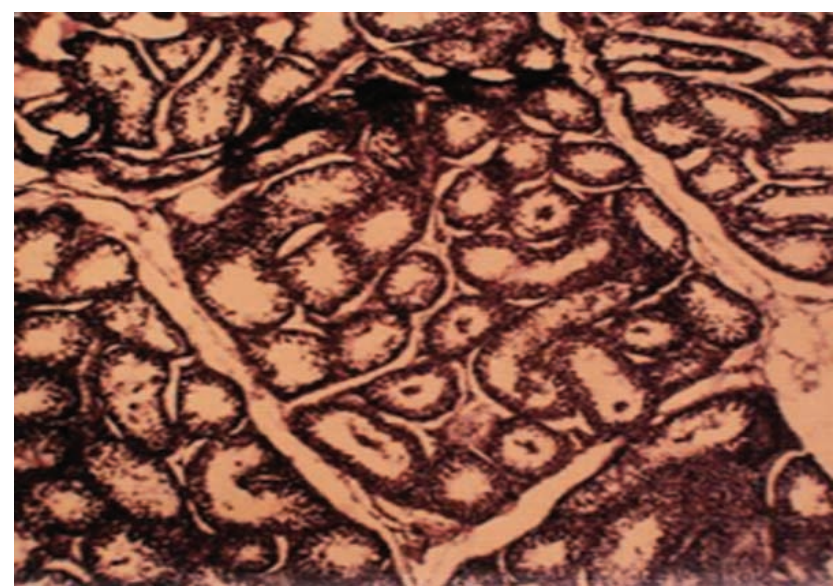

Fig. 3. Histological section of the testes stained using roselle extract, which was modanted with potassium alum, acidified with acetic acid and conterstained with $1 \%$ eosin. This gave a good nuclear/ cytoplasmic differentiation though with reduced affinity for the counterstain (eosin).

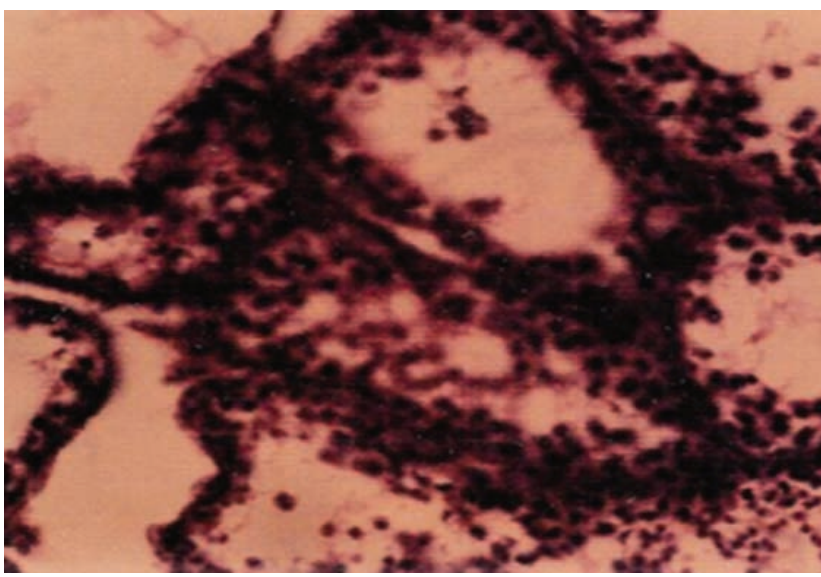

Fig. 4. Histological section of the testes stained using roselle extract, which was modanted with potassium alum, made basic with ammonia and countertained with $1 \%$ eosin. This gave a poor nuclear/cytoplasmic differentiation and with more up take of the counterstain (eosin) resulting in pink disease.

section and counterstained with eosin (Fig. 4) the nuclear/ cytoplasmic differentiation was markedly reduced and the counterstain seemed to stain all the structures uniformly resulting in the so-called "pink disease". This observation showed that an alkaline environment creates an anionic electrical environment, which naturally favored the acidic dye (eosin).

The use of iron alum as mordant with roselle extract (Fig. 5) on the section of the testis showed a good nuclear/ cytoplasmic differentiation as observed with the potassium alum counterpart, but in this case the connective tissues were more clearly demonstrated. The increased nuclear/ cytoplasmic differentiation and demonstration of other connective tissue can be attributed to the facts that iron alum tends to form a stronger dye- lake bond than potassium alum.

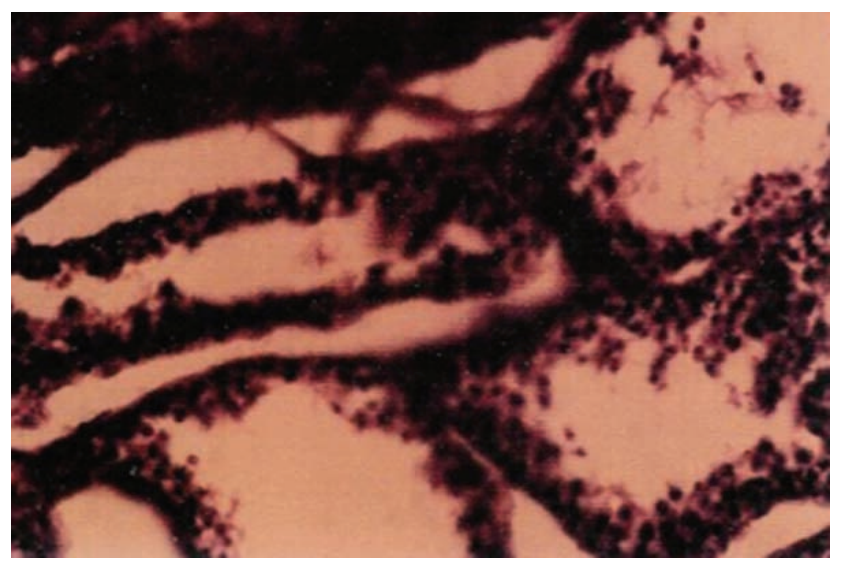

Figure 5: Histological section of the testes stained using roselle extract which was modanted with iron alum and counterstained with $1 \%$ eosin. This gave an excellent nuclear/cytoplasmic differentiation and made the connective tissues much more evident.

In conclusion Roselle can be a good substitute to haematoxylin as a nuclear stain especially when mordanted with iron or potassium alum. Acidifying with acetic acid has also been shown to enhance nuclear staining. The limitation of this study has been the inability to identify the iso-electric point ( $\mathrm{pH}$ point) at which both nuclei and cytoplasm of the cells could be stained simultaneously. Other factors that could be investigated are optimal temperatures for its use and compatibility with other counter stains.

Table I. Showing the various treatments. Treated (+) and Not trated (-).

\begin{tabular}{lcccccccc}
\hline \multirow{2}{*}{ Tissue type } & Extract & \multicolumn{2}{c}{ Staining time } & \multicolumn{2}{c}{ Mordant } & \multicolumn{2}{c}{$\mathbf{p H}$} & Counter Stain \\
\cline { 2 - 9 } & Water & $\mathbf{2 4 h r}$ & $\mathbf{3 0 m i n}$. & Potassium & Iron & Acidic & Basi & Eosin \\
\hline Testis & + & + & - & - & - & - & - & - \\
Testis & + & - & + & + & - & - & - & + \\
Testis & + & - & + & + & - & + & - & + \\
Testis & + & - & + & + & - & - & + & + \\
Testis & + & - & + & - & + & - & - & + \\
\hline
\end{tabular}


EGBUJO, E. C.; ADISA O. J. \& YAHAYA, A. B. Estudio de los efectos de tinción de la Rosa de Jamaica (Hibiscus sabdariffa) en cortes histológicos de testículo. Int. J. Morphol., 26(4):927-930, 2008.

RESUMEN: Este estudio describe la preparación y utilización de Roselle (Hibiscus sabddarifa) en la tinción diferencial de cortes histológicos de tejido testicular, para conocer su efecto sobre la tinción nuclear, citoplasmática y otras estructuras. Diversos tratamientos utilizando modificaciones de extracto de la planta en el agua, se llevaron a cabo en cortes de testículos de conejo. Distintos niveles de diferenciación de las estructuras nucleares y citoplasmáticas, así como de otras estructuras de este órgano, se han obtenido principalmente cuando se utiliza como tinción eosina al 1\%. El mejor resultado de tinción se obtuvo cuando se utilizó alumbre de hierro y cuando éste fue acidificado con ácido acético y se usó para teñir los cortes histológicos. La modificación del extracto acuoso a un pH alcalino utilizando amoníaco, dio una coloración más débil. El extracto de rosa de Jamaica muestra un razonable potencial para tinción nuclear, especialmente, cuando es mezclado con alumbre de hierro o aluminio de potasio y acidificada con ácido acético.

PALABRAS ClAVE: Hibiscus sabdariffa; Tinción; Testículo; Corte Histológico.

\section{REFERENCES}

Birkedal-Hansen, H. Eosin staining of gelatine. Histochemie, 36:73-87, 1973.

Bohmer, F. Zur pathologischen, Anatomie der Meningitis cerebromedularis epidemia. Aerztl. Intelligenzb. (Munchen), 12:539-50, 1865.

Goppert H. R. \& Cohn, F. Ueber die Rotation des Zellinhaltes von Nitella flexilis. Bot. Z., 7:681, 1849.

Kolliker, A. Manual of human Microscopic Anatomy. London, Hippolyte Bailliere, 1852.

Marshall P. N. \& Horobin R.W. Measurements of the affinities of basic and 'mordant' dyes for various tissue substrates. Histochenue, 36:303-12, 1973.
Correspondence to:

Dr. James O. Adisa

P. O. Box 1109, Jos

Plateau State

NIGERIA

Email: adisawuraola@yahoo.com

Received: 12-02-2008

Accepted: 26-08-2008 